COUNSENESIA
Indonesian Journal of Guidance and Counseling
$1(1)(2020): 64-71$
https:// http://ejournal.utp.ac.id/index.php/CIJGC

\title{
PELUANG DAN TANTANGAN LAYANAN BIMBINGAN DAN KONSELING DI ERA DISRUPSI
}

\author{
Eny Kusumawati \\ Universitas Tunas Pembangunan Surakarta \\ Email: one_enny@yahoo.com
}

\section{Info Artikel}

Riwayat Artikel

Diterima:

November 2020

Disetujui:

Desember 2020

Publikasi:

Desember 2020

\begin{abstract}
Abstrak
Era disrupsi adalah era dimana perubahan besar terjadi dalam kehidupan manusia. Perubahan tersebut terjadi lantaran terjadinya perubahan dan sumber energi yang berasal dari manusia menjadi serba mesin yang dijalankan secara otomatis lewat kekuatan yang bernama teknologi. Saat ini teknologi tidak dapat dilepaskan dari kehidupan manusia. Teknologi membantu setiap lini kehidupan. Teknologi menjadikan setiap kehidupan menjadi mudah. Perlu untuk betul-betul menggunakan teknologi kearah positif dan membangun. Salah satunya dalam kegiatan bimbingan dan konseling yang berbasis teknologi. Penggunaan teknologi dalam layanan bimbingan dan konseling mampu meningkatkan keterserapan materi yang diberikan dalam layanan bimbingan serta dapat mengefektifkan peran konselor sebagai fasilitator guna memandirikan peserta didik di sekolah. Konselor perlu untuk mengembangkan diri agar dapat mengaplikasikan teknologi kedalam layanan bimbingan dan konseling guna menciptakan layanan bimbingan dan konseling yang inovatif, kreatif, adaptif serta fleksibel di era disrupsi ini.
\end{abstract}

\section{Kata kunci: Teknologi, Layanan Bimbingan dan Konseling}

\begin{abstract}
Abstrac
The era of disruption is an era where major changes occur in human life. These changes occur due to changes and the source of energy that comes from humans into machines that run automatically through the power called technology. Currently technology cannot be separated from human life. Technology helps every line of life. Technology makes every life easy. It is necessary to really use technology in a positive and constructive way. One of them is in technology-based guidance and counseling activities. The use of technology in guidance and counseling services is able to increase the absorption of the material provided in guidance services and can streamline the role of the counselor as a facilitator in order to independent students in schools. Counselors need to develop themselves so that they can apply technology to guidance and counseling services in order to create guidance and counseling services services that are innovative, creative, adaptive and flexible in this era of disruption.
\end{abstract}

Key Word: technology, guidance and counseling services 


\section{PENDAHULUAN}

Perkembangan teknologi yang semakin pesat berdampak pada semua bidang termasuk bidang pendidikan. Beberapa tahun yang lalu semua hal yang dilakukan seseorang dalam kehidupannya dapat dilakukan sendiri (masih manual atau masih menggunakan potensi dalam diri seseorang tersebut), akan tetapi hal tersebut untuk saat ini berubah dan bertolak belakang dengan kondisi saat ini. Sebagai salah satu contohnya, beberapa tahun yang lalu sistem parkir masih menggunakan jasa manusia sebagai hal yang pokok, akan tetapi sekarang terdapat peralihan dalam hal tersebut yaitu dengan adanya e-parking. Sebagai contoh lainnya dalam bidang bimbingan dan konseling beberapa tahun yang lalu pemanfaatan layanan Bimbingan dan Konseling harus dilakukan face to face, akan tetapi semakin berkembangnya teknologi proses kegiatan layanan bimbngan dan konseling dapat dilakukan dengan memanfaatkan teknologi salah satunya dengan memanfaatkan konseling online atau cyber counselling.

Dengan kemajuan dan perkembangan teknologi yang semakin pesat tidak dipungkiri terdapat permasalahan perkembangan teknologi bidang bimbingan dan konseling yaitu tidak semua konselor mampu beradaptasi dengan perkembangan kemajuan teknologi. Ketidakmampuan guru bimbingan dan konseling/konselor dalam menggunakan teknologi akan berdampak terhadap proses dan hasil layanan. Sebagai contohnya jika guru bimbingan dan konseling /konselor hanya ceramah tanpa menggunakan teknologi sebagai media maka peserta didik akan mengalami kebosan. Kebosanan peserta didik menyebabkan peserta didik tidak tertarik dan pesan yang akan disampaikan tidak bisa diterima. Oleh karena itu, untuk mengatasi kebosanan peserta didik dalam mengikuti layanan maka penting bagi konselor untuk memanfaatkan teknologi ini.

Perubahan yang terjadi tersebut, tidak terlepas dengan semakin berkembang dan majunya teknologi saat ini. Teknologi mulai memasuki semua lini termasuk bidang keilmuan, salah satunya adalah bimbingan dan konseling. Menurut Cabanis dalam Bangunan B.N (2015), terdapat 8 potensi teknologi computer berbasis internet yang dapat digunakan untuk bimbingan dan konseling: (1) Email, yang berfungsi sebagai terapi, screening client/therapist, surat menyurat untuk penjadwalan perjanjian, monitoring intersessions, dan tindak lanjutpost therapeutic, transfer rekaman klien, refereal, masukan, pekerjaan rumah, penelitian, dan collegial professional, (2) Website/Homepages, berpotensi untuk informaasi dan publikasi, (3) Komputer konferensi video, berfungsi untuk membantu konselor dalam terapi, pekerjaan rumah, refereal, dan konsultasi, (4) Sistem bulletin board/ newsgroup untuk konsultasi, referral atau alih tangan kasus, sumber daya untuk informasi dan untuk kegiatan assosiasi professional, (5) simulasi terkomputerisasi untuk supervise dan pelatihan kompetensi, (6) pangkalan data untuk penelitian, sumber informasi perpustakaan, transfer rekaman klien, penilaian dan analisis, (7) chaat rooms/electronic discussioan groups, untuk terapi kelompok dan assesmen/pengukuran, (8) softwere berbasis internet berpotensi untuk pelatihan ketrampilan dan keahlian, bantuan diri sendiri, dan ketrampilan serta pekerjaan rumah. Sedangkan teknologi computer berbasis non internet yang dapat digunakan oleh konselor untuk kegiatan layanan bimbingan dan konseling adalah (1) spreadsheet yakni untuk tata kearsipan, data organisasi, informasi konseli dan penelitian, (2) pemrosesan kata, dapat digunakan untuk tata kearsipan, surat menyurat, marketing, publikasi dan penelitian, (3) software non internet untuk pelatihan ketrampilan managemen kantor, sumber referensi dan catatan khusus

Dengan adanya internet saat ini konselor dapat memberikan layanan bimbingan dan konseling tanpa harus berhadapan langsung dengan siswa (Furlonger \& Gencic, 2014). 
Dengan demikian siswa dapat memperoleh informasi dalam lingkup yang luas. Perkembangan konseling juga tidak lepas dari pengaruh teknologi. Saat ini konseling dapat diselenggarakan degan berbagai media yang memungkinkan hubungan konseling jarak jauh (Prayitno, 2012). Penghantaran konseling jarak jauh yang dibantu oleh teknologi terus bertumbuh dan mengalami proses evolusi. Perkembangan yang pesat dan penggunaan internet untuk menghantarkan informasi dan menyokong komunikasi telah menghasilkan bentuk-bentuk konseling baru salah satunya adalah konseling jarak jauh yang dibantu teknologi, yang dapt diperbaharui dengan mudah kaitannya dengan evolusi teknologi dan praktiknya ( Ardi. Z dkk, 2013)

Selain hal tersebut di atas, perkembangan teknologi yang semakin pesat diberbagai sektor kehidupan terlebih dalam layanan bimbingan dan konseling akhirnya akan mendorong segala sesuatu yang semakin cepat dan canggih pula pada era disrupsi saat ini. Untuk itu agar dapat mengikuti perkembangan teknologi tersebut terkhusus bagi seorang konselor diharapkan mampu untuk meningkatkan kompetensi yang dimilliki untuk disesuaikan dengan kemajuan teknologi. Selain itu seorang konselor juga diharapkan untuk menambah wawasan, pengetahuan,ketrampilan serta dapat menyeseuaikan dan menerapkan perkembangan teknologi dalam bidang Bimbingan dan Konseling ( Sanaky, 2005)

\section{PEMBAHASAN}

\section{Pentingnya Teknologi dalam Bimbingan Konseling}

Urgensi kegiatan Bimbingan dan Konseling mengacu pada perkembangan dan kemajuan teknolgi yang mutakhir, salah satunya ialah penggunaan alat atau media komunikasi serta informasi elektronik baik secara online maupun offline. Penggunaan media teknologi yang mutakhir akan senantiasa merubah gaya serta penerapan bimbingan dan konseling yang konvensional. Sebagaimana tujuan dari kemajuan teknologi yaitu untuk mengefisienkan atau mempermudah akses informasi, maka penerapannya dalam bimbingan dan konseling juga mengacu pada cara yang sama tanpa mengubah konteks dari bimbingan dan konseling tersebut.

Alat-alat atau media dalam akses informasi di era global ini sangat beragam dan mutakhir, seperti telepon selular, komputer, internet dan media lainnya yang langsung atau online ataupun yang tidak langsung atau offline. Maka semua media teknologi informasi tersebut akan mempermudah akses pemberian bantuan terhadap individu jika dimanfaatkan secara tepat guna dan terlatih. Oleh karena itu, profesional di bidang bimbingan dan konseling yang selanjutnya disebut dengan konselor, dituntut untuk dapat menggunakan serta terlatih dalam penggunaan dan penerapan konseling melalui media teknologi.

Sebagaimana upaya bimbingan dan konseling yaitu memfasilitasi konseli, maka penggunaan teknologi informasi atau media elektronik penunjang proses konseling akan sangat dibutuhkan agar konseli dapat memanfaatkan layanan bimbingan dan konseling secara efisien serta tidak terkesan ketinggalan zaman. Jika layanan bimbingan konseling masih menerapkan cara-cara konvensional dalam era teknologi yang semakin maju, maka layanan tersebut akan ditinggalkan oleh konseli yang akan mengakibatkan degradasi moral serta ketidakmampuan konseli dalam memecahkan serta mengoptimalkan tugas perkembangan yang harus dilaluinya secara mandiri. Maka jika hal tersebut terjadi, akan banyak individu yang mengalami kesulitan dalam pemahaman diri dan akan cenderung masuk ke dalam zona kebebasan yang kebablasan tanpa adanya bimbingan yang bersifat mengembangkan kepribadian yang sehat. 
Maka dari hal tersebut, penerapan atau pemanfaatan teknologi informasi dalam bimbingan dan konseling menjadi suatu urgensi tersendiri dalam penyesuaian kondisi zaman atau era yang sangat global. Salah satu yang menjadi pertimbangan perlunya bimbingan dan konseling menyesuaikan terhadap era yang global serta serba teknologi tersebut, yaitu pertimbangan dampak dari era globalisasi itu sendiri. Seperti diketahui, bahwa kemajuan teknologi informasi yang tidak dimanfaatkan secara tepat akan memicu timbulnya dampak negatif dari penggunaan teknologi informasi tersebut. Maraknya penyalahgunaan teknologi informasi salah satunya internet yaitu beredarnya pornografi yang tanpa batas atau tayangan tayangan kekerasan yang tidak pantas untuk disaksikan terutama oleh para remaja dan anak-anak. Ketika hal tersebut kian marak karena terlalu bebasnya akses informasi tanpa ada bimbingan, maka akan merusak generasi muda juga akan muncul degradasi mental remaja dari dampak tersebut. Oleh karena itu, dalam hal inilah bimbingan dan konseling berperan sebagai pembimbing untuk mencegah hal tersebut. Tindakan preventif melalui kegiatan bimbingan dan konseling terhadap para remaja dalam hal penyalahgunaan teknologi informasi, akan menjadi suatu batasan internal terhadap remaja menghadapi kebebasan tanpa batas di dunia maya. Maka dari itulah layanan bimbingan dan konseling yang menyesuaikan dengan kondisi zaman yang mutakhir dan global, menjadi sangat penting dan diperlukan dalam membangun kualitas kehidupan generasi muda yang terhindar dari dampak negatif arus informasi yang tak berbatas.

Salah satu penerapan teknologi informasi dalam BK diantaranya pada penyelenggaraan dukungan sistem. Dukungan sistem dapat berupa sarana-prasarana, sistem pendidikan, sistem pengajaran, visi-misi sekolah dan lain sebagainya. Berbicara sarana-prasarana, memasuki dunia globalisasi dengan pesatnya teknologi dan luasnya informasi menuntut dunia konseling untuk menyesuaikan dengan lingkungannya agar memenuhi kebutuhan masyarakat luas.

Perkembangan teknologi sejatinya mempengaruhi perkembangan bimbingan dan konseling juga. Hal ini bersifat mutlak,karena apabila bimbingan dan konseling tidak bisa mengikuti perkembangan teknologi informasi,maka pelayanan bimbingan dan konseling akan tertinggal dan tidak bisa mengikuti perkembangan jaman. Sedangkan dalam hal ini,bimbingan dan konseling dituntut untuk bisa mengimbangi dinamika kehidupan individu yang terus berkembang.

Kedudukan teknologi dalam bimbingan dan konseling berada di dalam layanan dukungan system. Ini berarti bahwa teknologi informasi menjadi salah satu sarana untuk mendukung layanan bimbingtan dan konseling. Dengan teknologi informasi,seorang konselor dapat berkreasi dalam memberikan layanan,sehingga siswa tidak merasa bosan.

Urgensi teknologi informasi dalam bimbingan konseling menuntut konselor untuk dapat menguasai teknologi agar dapat memudahkan dalam pemberian pelayanan konseling kepada kliennya. Memanfaatkan TI bagi seorang guru sudah semakin urgen tampaknya, dan khusus bagi kita guru BK, banyak sekali kreasi yang dapat dibuat dalam melayani konseli. Dalam aplikasinya teknologi dan informasi ini lebih diarahkan untuk membantu konseli dalam pemenuhan kebutuhan informasi terutama ketika seorang konseli ingin melanjutkan studi ke jenjang selanjutnya. Kelebihan daripada ini, konseli lebih cepat mengakses semua informasi yang ada dan tidak harus melakukan proses konseling secara langsung.

Pemanfaatan teknologi informasi dalam bimbingan dan konseling memberikan dampak positif dan negative. Dampak positifnya adalah semakin mudahnya interaksi antara konselor dengan kliennya,yang tidak harus bertatap muka dalam pelaksanaan proses 
bimbingan dan konseling. Teknologi informasi juga memudahkan klien untuk mendapatkan informasi yang dia butuhkan pada saat itu juga.

Dalam proses bimbingan dan konseling masih banyak yang belum mengetahui pemanfaatan media teknologi informasi untuk menunjang layanan bimbingan dan konseling. Konselor sekolah tidak semuanya mengerti atau paham tentang pengguanaan internet. Padahal internet merupakan media yang sangat efektif dalam proses layanan bimbingan dan konseling. Untuk itu, perlu adanya suatu sosialisasi untuk meningkatkan kinerja konselor di sekolah dalam hal memanfaatkan kemajuan teknologi informasi agar nantinya bidang bimbingan dan konseling tidak lagi menjadi bidang layanan yang membosankan dan menjenuhkan. Tidak hanya konselor yang perlu diberikan sosialisasi. Para konseli yang dalam hal ini adalah siswa juga perku diberikan suatu sosialisasi agar kemajuan teknologi informasi tersebut bisa dimanfaatkan sesuai apa yang diharapkan. Dengan kata lain, teknologi informasi tersebut tidak disalahgunakan untuk hal yang negatif.

Jika konselor dan konseli sudah paham akan manfaat dan pentingnya teknologi dalam menunjang proses layanan bimbingan dan konseling, maka ke depannya bimbingan dan konseling akan menjadi suatu bidang pendidikan yang inovatif dan efisien berkat kemajuan teknologi informasi namun tetap tidak menghilangkan esensi dari layanan bimbingan dan konseling itu sendiri. Selain itu menurut Zamroni (2012) keuntungan dari guru BK menyelenggarakan BK dengan bantuan teknologi, konselor memiliki kemampuan untuk menggunakan sumber teknologi lain yang dapat dimanfaatkan dalam bimbingan konseling. Hal ini dapat meningkatkan kemampuan diri dan konselor itu sendiri serta membangun prestise dikalangan guru lain disekolah.

Pentingnya penggunaan teknologi informasi ini tentunya dapat dilihat dari berbagai aspek, penggunaan teknologi informasi juga dapat memberikan pengaruh terhadap seorang guru BK. Seorang guru konselor yang mampu memanfaatkan teknologi informasi diharapkan konselor mampu berpikir kreatif, inovatif terhadap isu-isu yang terjadi saat ini. Selain hal tersebut, pengembangan layanan bimbingan konseling ini tentu membuat minat siswa untuk mengikuti layanan BK menjadi meningkat. Hal ini juga sejalan dengan layanan BK yang adaptif, artinya layanan BK harus dapat menjawab/menyesuaikan dengan kebutuhan peserta didik di era disrupsi ini. Beberapa pengembangan dalam layanan BK merupakan upaya yang dilakukan untuk dapat menjawab kebutuhan dunia sebagai imbas revolusi industri 4.0. teknologi dalam layanan BK memiliki kontribusi yang sangat besar bagi terlaksananya layanan $\mathrm{BK}$, peran teknologi dalam BK diantaranya mempermudah dalam merancang, memproses dan mengolah data terkait pelayanan BK (Setiawan. A, 2016)

\section{Peranan Teknologi dalam Bimbingan dan Konseling}

Teknologi informasi telah menjadi fasilitas bagi kegiatan berbagai sektor kehidupan, dan telah menyentuh layanan bimbingan dan konseling. Teknologi informasi dalam layanan bimbingan dan konseling masuk kepada dukungan sistem bimbingan dan konseling sebagai suatu proses pemberian bantuan kepada individu (konseli), dilaksanakan melalui berbagai macam layanan. Layanan tersebut saat ini, pada saat jaman semakin berkembang, tidak hanya dapat dilakukan dengan tatap muka secara langsung, tapi juga bisa dengan memanfaatkan media atau teknologi informasi yang ada. Tujuannya adalah tetap memberikan bimbingan dan konseling dengan cara-cara yang lebih menarik, interaktif, dan tidak terbatas tempat, tetapi juga tetap memperhatikan azas-azas dan kode etik dalam bimbingan dan konseling. 
Achmad Juntika Nurihsan (2007), mengetengahkan bahwa penggunaan teknologi informasi, khususnya internet dalam layanan bimbingan dan konseling adalah dengan sebutan e-counseling. Melalui layanan ini dirasa cukup efektif dan efisien dalam proses konseling jarak jauh yang dilakukan oleh konselor dan klien untuk membantu masalahmasalah yang dihadapi klien. Para konseli juga perlu diberikan suatu sosialisasi agar kemajuan teknologi informasi tersebut bisa dimanfaatkan sesuai apa yang diharapkan. Dengan kata lain, teknologi informasi tersebut tidak disalahgunakan untuk hal yang negatif. Jika konselor dan konseli sudah paham akan manfaat dan pentingnya teknologi informasi dalam menunjang proses layanan bimbingan dan konseling, maka ke depannya bimbingan dan konseling akan menjadi suatu bidang pendidikan yang inovatif dan efisien berkat kemajuan teknologi informasi namun tetap tidak menghilangkan esensi dari layanan bimbingan dan konseling itu sendiri.

Menurut Moh. Surya dalam blog I Gede Tresna (2014) mengemukakan bahwa sejalan dengan perkembangan teknologi komputer, interaksi antara konselor dengan klien tidak hanya dilakukan melalui hubungan tatap muka tetapi dapat juga dilakukan melalui hubungan secara virtual (maya) melalui internet dalam bentuk "cyber counseling". Layanan bimbingan dan konseling ini merupakan salah satu model pelayanan konseling yang inovatif dalam upaya menunjukkan pelayanan yang praktis dan bisa dilakukan dimana saja asalkan ada koneksi atau terhubung dengan internet.

Peranan bimbingan dan konseling mengacu pada perkembangan serta kemajuan teknologi yang mutakhir, salah satunya ialah penggunaan alat atau media komunikasi serta informasi elektronik baik secara on line maupun off line. Penggunaan media teknologi yang mutakhir akan senantiasa merubah gaya serta penerapan bimbingan dan konseling yang konvensional. Sebagaimana tujuan dari kemajuan teknologi yaitu untuk mengefisienkan atau mempermudah akses informasi, maka penerapannya dalam bimbingan dan konseling juga mengacu pada cara yang sama tanpa mengubah konteks dari bimbingan dan konseling tersebut. Alat-alat atau media dalam akses informasi di era global ini sangat beragam dan mutakhir, seperti telepon selular, komputer, internet dan media lainnya yang langsung atau online ataupun yang tidak langsung atau off line. Maka semua media teknologi informasi tersebut akan mempermudah akses pemberian bantuan terhadap individu jika dimanfaatkan secara tepat guna dan terlatih.

Menurut Yoezron (2010), teknologi informasi memiliki beberapa fungsi dan peranan dalam bimbingan konseling yaitu: Pertama Publikasi, teknologi informasi dimanfaatkan sebagai sarana pengenalan kepada masyarakat luas dan juga sebagai pemberi informasi mengenai BK. Kedua Pelayanan dan bantuan, dalam fungsi ini bimbingan konseling dilakukan secara tidak langsung dengan bantuan teknologi informasi. Ketiga Pendidikan, dikatakan demikian karena di dalam informasi yang diberikan melalui sarana TI ini mengandung unsur pedidikannya.

Banyak sekali manfaat yang dapat diperoleh dari teknologi komputer dalam menunjang profesionalitas kerja konselor, maka konselor perlu mengetahui potensi apa yang terkandung pada teknologi komputer. Sesuai dengan kompetensi akademik konselor disebutkan bahwa seorang konselor professional harus menguasai khasanah teoritik dan prosedural termasuk teknologi dalam bimbingan dan konseling. Walaupun kegiatan konseling dilakukan dengan jarak jauh namun kerahasian konseli harus tetap terjaga. Media layanan dapat menggunakan telepon, telekonferensi, dan internet. Layanan bimbingan dan konseling tidak selalu face to face atau tatap muka. Terdapat layanan yang lebih mudah yaitu dengan cyber counseling yang memungkinkan konseli tidak merasa malu/canggung yang bisa dilakukan kapan dan dimana saja. Pemanfaatkan teknologi 
informasi di zaman modern menjadi sangat relevan ketika diterapkan dalam kegiatan bimbingan dan konseling. Oleh karena itu, hal ini diharapkan menjadi efektif untuk membantu individu dalam perkembangannya secara optimal dan menyesuaikan dengan kemajuan zaman tanpa tergerus oleh pengaruh negatif dari kemajuan tersebut.

\section{Kelebihan/Keuntungan Penggunaan Teknologi Informasi dalam Bimbingan Konseling}

Menurut Zamroni (2012) keuntungan dari guru BK menyelenggarakan BK dengan bantuan teknologi, konselor memiliki kemampuan untuk menggunakan sumber teknologi lain yang dapat dimanfaatkan dalam bimbingan konseling. Hal ini dapat meningkatkan kemampuan diri dan konselor itu sendiri serta membangun prestise dikalangan guru lain disekolah. Lebih lanjut kelebihan atau keuntungan pelayanan bimbingan konseling melalui teknologi informasi, diantaranya :

1. Pelayanan melalui teknologi informasi mudah di akses.

2. Tidak membutuhkan biaya transportasi

3. Mengurangi kesulitan jadwal yang berkaitan dengan program kelompok

4. Pelayanan melalui teknologi informasi bersifat semi anonim

5. Klien lebih mau terbuka berbicara tentang masalahnya karena ia tidak berkomunikasi secara face to face, sehingga ia dapat lebih siap dan terbuka

6. Pelayanan melalui teknologi informasi dan komunikasi berbasis individu

7. Konselor dapat menyesuaikan kesiapan klien dalam mengambil tindakan yang diperlukan, memotivasi diri, dan meningkatkan keterampilan kliennya

8. Pelayanan melalui teknologi informasi dan komunikasi formatnya harus memfasilitasi konseling yang proaktif

9. Setelah klien membuka komunikasi via teknologi informasi awal, maka konselor berinisiatif untuk memulai suatu kontak berikutnya sehingga ia dapat menciptakan suatu taraf terapis berupa dukungan sosial dan klien bertanggung jawab selama proses penyembuhannya

10. Pelayanan melalui teknologi informasi formatnya menggunakan ijin protokol yang terstruktur. Hal ini memberikan konselor suatu kerangka kerja tertulis yang dapat memastikan pemenuhan topik penting ketika bekerja khusus kepada masingmasing individu pada setiap sesi, sehingga menghasilkan suatu intervesi yang ringkas, terpusat, dan sesuai dengan pribadi klien.

\section{PENUTUP}

Teknologi informasi merupakan faktor penting dalam proses pelayanan bimbingan dan konseling oleh guru bimbingan dan konseling/konselor sekolah. Adanya pemanfaatan teknologi informasi diharapkan dapat mendorong guru bimbingan dan konseling/konselor untuk lebih kreatif, inovatif, variatif dalam mencari informasi terbaru dalam proses pelayanan. Oleh sebab itu, teknologi hasus dimanfaatkan dengan sebaik dan seoptimal mungkin oleh guru bimbingan dan konseling/konselor agar pelayanan yang diberikan bisa memberikan hasil yang optimal. Agar teknologi bisa dimanfaatkan secara optimal maka tidak akan terlepas dari persepsi atau penilaian guru bimbingan dan konseling /konselor tentang pentingnya teknologi informasi, kemauan, pengetahuan, dan keterampilan guru bimbingan dan konseling/konselor dalam memanfatkannya untuk proses pelayanan. Guru 
bimbingan dan konseling/konselor yang memiliki pengetahuan dan keterampilan maka akan cenderung memanfatkan teknologi dalam bimbingan dan konseling. Selain hal tersebut, para akademisi maupun praktisi dibidang bimbingan dan konseling diharapkan untuk selalu meningkatkan kemampuan diri dalam menggunakan teknologi dalam bimbingan dan konseling, guna mengembangkan layanan bimbingan dan konseling yang kreatuf, inovatif, adaptif dan dapat memenuhi kebutuhan peserta didik di era disrupsi ini serta selalu melakukan kolaborasi dengan berbagai pihak guna ketercapaiannya dengan tujuan bimbingan dan konseling yang menyeluruh

\section{DAFTAR PUSTAKA}

Ardi, Z.,\&Yendi, M,F.,\&Ifdil. 2013. Konseling Online: Sebuah Pendekatan Teknologi Dalam Pelayanan Konseling. Jurnal Konseling Pendidikan

Bangun, Br,.\&Saragih. H.A. 2015. Pengembangan Media Web Bimbingan Konseling Jurnal Teknologi Informasi \& Komunikasi Pendidikan

Leksana, M, D., dkk. 2013. Pengembangan Modul Bimbingan Karir Berbasis Multimedia Interaktif Untuk Meningkatkan Kematangan Karir Siswa. Jurnal Bimbingan Konseling, 2(1), 1-9

Nurihsan, Ahmad Juntika. 2007. Strategi Layanan Bimbingan\&Konseling. Bandung: Refika Aditama.

Prayitno. 2012. Jenis Layanan dan Kegiatan Pendukung Konseling. Padang: Universitas Negeri Padang

Rahmani, Yoezron Isman. 2010. Urgensi Teknologi Informasi dalam Bimbingan dan Konseling. [Online]. Tersedia di: http://yoezronbloon.blogspot.com [21 Mei 2014]

Setiawan, A,M. 2016. Peranan Teknologi Informasi Dalam Bimbingan Konseling. Bitnet Jurnal Pendidikan Teknologi Informasi, 1 (1), 46-49

Tresna, I Gede. 2014. Teknologi Informasi dalam BK. Tersedia di: http://tresnainnovation.blogspot.com [28 Mei 2014]

Sanaky, H. A. H. 2005. Setifikasi dan Profesionalisme Guru di Era Reformasi Pendidikan. El Tarbawi

Zamroni. 2002. Pemanfaatan Teknologi Informasi (TI) Dalam Layanan Bimbingan dan Konseling Sebagai Representasi Berkembangnya Budaya Profesional Konselor dalam Melayani Siswa. E-journal Bimbingan Konseling, 2(1) 